\title{
Development of Prostate Cancer Organoid Culture Models in Basic Medicine and Translational Research
}

\author{
Mohamed Elbadawy ${ }^{1,2}\left(\right.$, Amira Abugomaa ${ }^{1,3}$, , Hideyuki Yamawaki ${ }^{4}$, Tatsuya Usui ${ }^{1, *}$ and \\ Kazuaki Sasaki ${ }^{1}$ \\ 1 Laboratory of Veterinary Pharmacology, Department of Veterinary Medicine, Faculty of Agriculture, \\ Tokyo University of Agriculture and Technology, 3-5-8 Saiwai-cho, Fuchu, Tokyo 183-8509, Japan; \\ mohamed.elbadawy@fvtm.bu.edu.eg (M.E.); s193249s@st.go.tuat.ac.jp (A.A.); skazuaki@cc.tuat.ac.jp (K.S.) \\ 2 Department of Pharmacology, Faculty of Veterinary Medicine, Benha University, Moshtohor, \\ Toukh 13736, Elqaliobiya, Egypt \\ 3 Faculty of Veterinary Medicine, Mansoura University, Mansoura 35516, Dakahliya, Egypt \\ 4 Laboratory of Veterinary Pharmacology, School of Veterinary Medicine, Kitasato University, Towada, \\ Aomori 034-8628, Japan; yamawaki@vmas.kitasato-u.ac.jp \\ * Correspondence: fu7085@go.tuat.ac.jp; Tel./Fax: +81-42-367-5769
}

Received: 24 February 2020; Accepted: 19 March 2020; Published: 25 March 2020

check for updates

\begin{abstract}
Prostate cancer (PC) is the most prevalent cancer in men and the second main cause of cancer-related death in Western society. The lack of proper PC models that recapitulate the molecular and genomic landscape of clinical disease has hampered progress toward translational research to understand the disease initiation, progression, and therapeutic responses in each patient. Although several models have been developed, they hardly emulated the complicated PC microenvironment. Precision medicine is an emerging approach predicting appropriate therapies for individual cancer patients by means of various analyses of individual genomic profiling and targeting specific cancer pathways. In PC, precision medicine also has the potential to impose changes in clinical practices. Here, we describe the various PC models with special focus on PC organoids and their values in basic medicine, personalized therapy, and translational researches in vitro and in vivo, which could help to achieve the full transformative power of cancer precision medicine.
\end{abstract}

Keywords: organoid; prostate cancer; precision medicine; translational research; drug resistance

\section{Introduction}

Prostate cancer (PC) is one of the most prevalent cancers worldwide and the second common cause of cancer-related deaths among American men [1]. It is apart from hereditary cases with a peak incidence in aged men (75 years ) and the epidemiology remains unclear [2]. Human PC mainly exhibits low grade with slow progression [3] and can be easily diagnosed by measuring the plasma concentration of prostate-specific antigen (PSA) protein [4]. Although the overall death rate due to PC is gradually decreasing due to the improvements in early diagnosis and prevention, the late diagnosis of PC leads to advanced and metastatic disease in which the survival of patients shortens. In this case, the androgen deprivation therapy plus gonadal repression and/or chemotherapy is usually performed [5]. Despite initial responses, castration resistance ultimately ensues. Therefore, the development of new drugs with higher specificity and decreased toxicity is of utmost need in the severe PC disease.

The etiological origin of PC remains unclear due to the heterogeneity of the gland tissues [6]. Histologically, the prostate gland is composed of basal, luminal, and neuroendocrine cells embedded in a fibro-muscular stroma [7]. The basal layer (contains stem, transit-amplifying, and basal committed cells), constructs up to $40 \%$ of the total epithelium and expresses p63, cytokeratin (CK) 5, and 
estrogen receptor (ER) $\beta$. Due to the lack of androgen receptor (AR), they are androgen-independent. The luminal secretory cell layer accounts for the rest of epithelium and expresses CK 8/18, AR, and ER $\beta$ [8]. They are, therefore, dependent on androgen for their growth and survival [6,9]. The stroma of human prostate expresses mainly ER $\alpha$, while the neuroendocrine cells express chromogranin A and synaptophysin and have unknown functions.

It has been reported that receptors for androgen and estradiol play important roles in mediating the hormonal control of prostate cell stemness, transformation, growth, proliferation, invasiveness, and metastasis $[8,10,11]$. The androgen, through AR, enters the prostate cell nuclei and activates gene transcription [12]. Also, the ligand-bound AR acts in target cells at the non-transcriptional level [13], triggering the fast and temporal stimulation of Src tyrosine kinase which rises the active form of small-GTP binding proteins (Ras and Rac 1) and activates mitogen-activated protein kinases as well as focal adhesion kinase in PC cells [14]. Moreover, androgens also promote cell proliferation through the activation of PI3-K/Akt pathways [15]. Additionally, the androgen-triggered AR/filamin A complex is required for the motility, migration, and adhesion of NIH3T3, HT1080, and neuronal PC12 cells [16].

Estrogens, with androgens, trigger the hyperplasia and transformation of prostate as well as PC progression $[17,18]$. The high ER expression is associated with PC risk. Estrogens, through ER $\alpha$ and $\beta$, stimulate the signal transduction pathways including Src, adenylyl cyclase, MAPKs, and PI3-K, or mediate a rapid increase in intracellular calcium levels [14]. Migliaccio et al., reported that a rapid estradiol action mediated by ER $\beta$ leads to proliferation and cell cycle progression in LNCaP cells [19]. Also, estrogens via ER play a role in epithelial versus mesenchymal transition of prostate cancer cells [10]. Therefore, the selective targeting of AR and ER ( $\alpha$ or $\beta$ ) may be an attractive mean to restrict the growth and proliferation of PC cells.

In PC, the predisposing factors leading to a disruption of the epithelial lineage and basement membrane, are followed by a drift of cell population numbers with tumor growth via heterotypic signaling [20,21]. Although clarifying the cell origin of PC is important for establishing the new therapeutic strategy, it is the subject of considerable discussion.

Establishing experimental model systems for PC that precisely mimic both the genetic divergence and lineage specificity of cancer is critical to perceive the function of cancer-related genetic changes in tumorigenesis, tumor maintenance, and therapeutic sensitivity or resistance.

The 3D organoid culture systems have been shown to be valuable in clarifying the biology of various types of cancer diseases [22,23]. In PC, it is also useful in identifying tumor-initiating cells from an epithelial cell lineage. The patient-derived PC organoids can provide preclinical models to perceive the precision medicine by drug screening of individual patient samples [24].

In the present review, we discuss the potentials of PC organoids to identify the cell of origin, to study PC microenvironment, to screen genetic mutations, and to check drug sensitivity in each PC patient.

\section{Treatment Challenges Against PC}

Several kinds of treatments were used in PC, some of which are associated with drawbacks (Figure 1). The low grade of local PC is usually treated with surgical resection (radical prostatectomy) and/or radiotherapy (brachytherapy or external beam radiotherapy) [25], followed by routine monitoring of PSA level in the blood to predict the recurrence [26]. However, prostatectomy is usually followed by erectile dysfunction and urinary incontinence $[27,28]$. Radiotherapy is also associated with more bowel and rectal disturbances [29].

Since most PC patients are androgen-driven adenocarcinoma, androgen-deprivation therapy (ADT) is the main treatment for patients with locally advanced, recurrent, and metastatic disease [30] with or without the addition of chemotherapy or the potent androgen synthesis inhibitor, abiraterone acetate [31,32].

Although ADT is effective at first, the long-lived patients finally develop a metastatic castration-resistant PC (mCRPC), the more advanced form of the disease with a 2-3 years survival 
rate [33]. Antiestrogen-based therapy also has values in the treatment of PC [34]. Although immunotherapy has shown fundamental aids for several types of cancer, it only presented a marginal benefit for $\mathrm{mCRPC}$, probably due to its immunosuppressive tumor microenvironment [35]. Although immunotherapy based on the blockade of immune checkpoint inhibitors plays a role in the treatment of most advanced cancers [36], PC is still in its infancy [37].

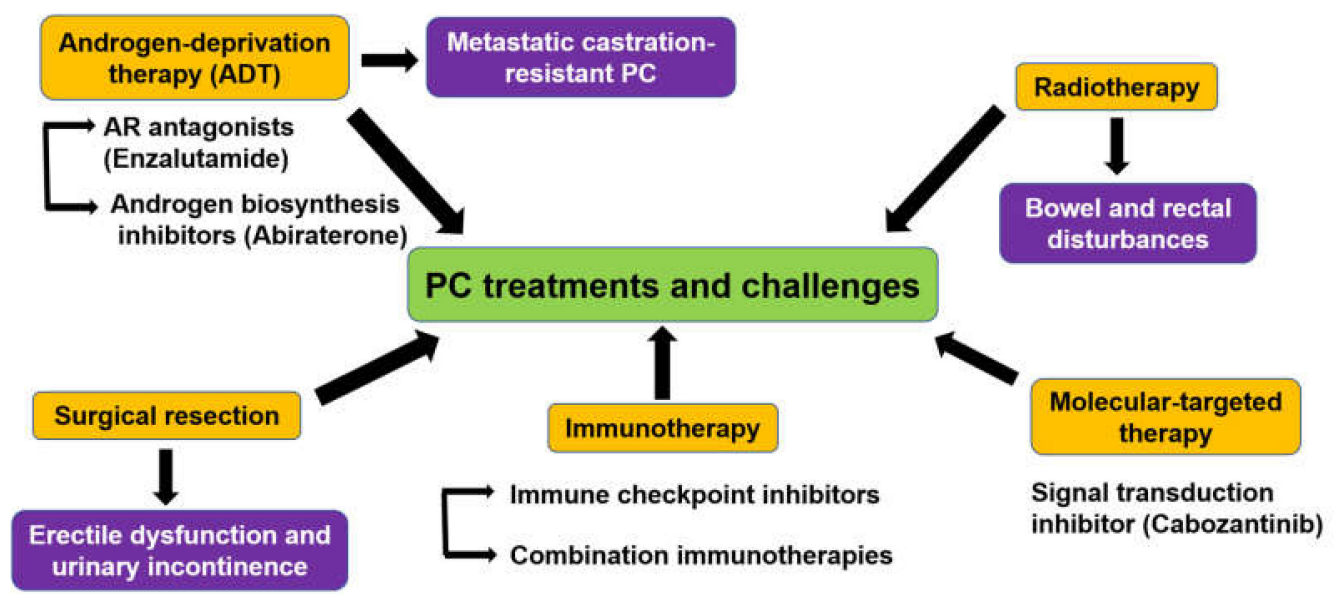

Figure 1. Outlines of current treatments of prostate cancer (PC) and their challenges. The recent treatments involve surgical resection, radiation therapy, chemotherapy, androgen-deprivation therapy (ADT), immunotherapy, and molecular-targeted therapy.

\section{Experimental Models to Study PC}

Establishing experimental model systems either in vitro or in vivo that precisely mimic the genetic divergence, lineage specificity, microenvironment, and pathophysiology of the tumor is critical to perceive the function of cancer-related genetic changes in tumorigenesis, tumor maintenance, and therapeutic sensitivity or resistance in PC disease. As shown in Figure 2, the experimental models have been established in the previous studies.

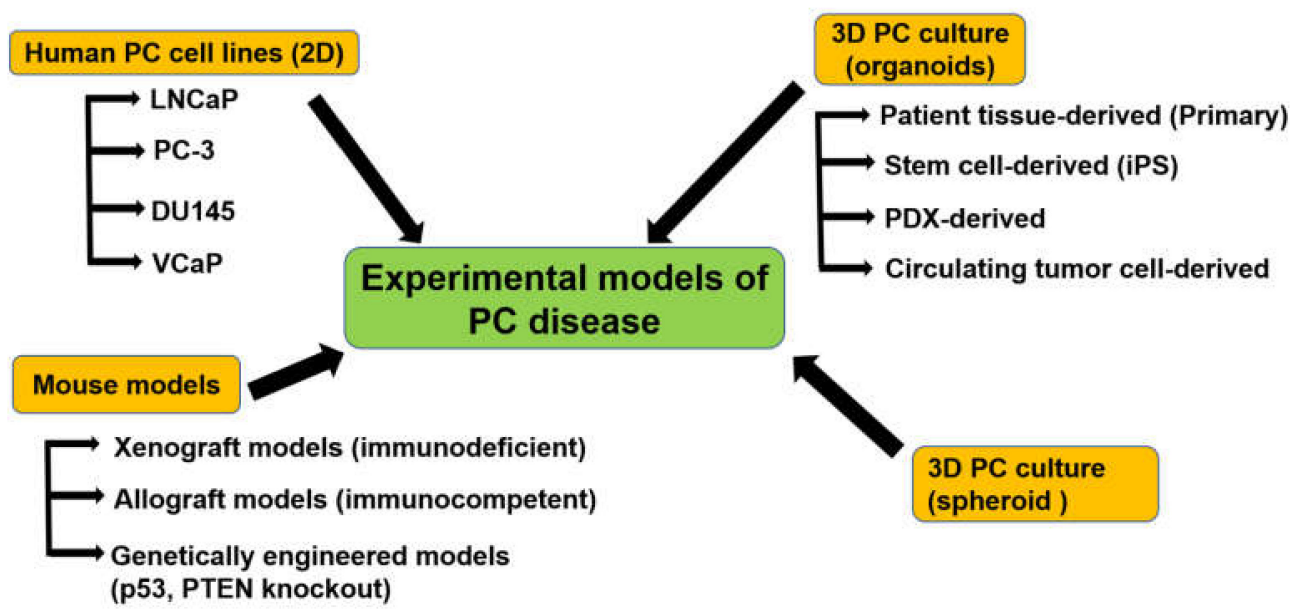

Figure 2. Main models to study PC disease and their subtypes. PDX: Patient-derived xenograft.

\subsection{PC Cell Lines}

Cell lines have been used for realizing the function of genetic and molecular changes in cancer such as the discovery of genomic biomarkers of anti-cancer drug sensitivity [38-40]. In PC, the scarcity of classical cell line models is mainly due to the difficulty in propagating PC cells in vitro for a long 
period, because most PC cells do not grow in a traditional culture medium. Despite the high prevalence of PC among men worldwide, only a few PC cell lines have been established via many trials by multiple researchers. As shown in Table 1, these cell lines were established from original tissues of PC, metastasized PC, and PC xenograft models from the primary tumor or the metastasized ones. Examples of these cell lines are LNCaP [41,42], PC-3 [43,44], DU145 [45,46],VCaP [47,48], NCI-H660 [49], PC346 [50], 22Rv1 [51], KUCaP [52], MDA PCa 2a and MDA PCa 2b [53,54]. Among them, DU145, PC-3, and LNCaP are the most widely used ones in PC research $[55,56]$.

Additionally, several sublines have been established from the classical PC cell lines, particularly the LNCaP one. While the original LNCaP cells are sensitive to androgen, their sublines, LNCaP-abl and LNCaP-LTAD, generated by removing androgen from the culture medium, are androgen-resistant [57, 58]. Moreover, various resistant PC sublines have been generated by incubating the original cell lines with anti-androgen or chemotherapeutic agents (Table 2).

Although there are the ease of use, reproducibility, and cost-effectiveness, the major limitations of PC cell lines are genetic shift or acquisition of mutations due to long-term culture. Recent papers showed important genetic alterations in PC patients, which might regulate prostate tumorigenesis $[59,60]$, many of which (e.g., CHD1 loss, Forkhead box protein (FOX)A1 mutation, Speckle-type POZ protein (SPOP) mutation, etc.) are not demonstrated in PC cell lines [61]. Moreover, the lack of relevant clinical data, loss of tumor heterogeneity, and 2D cell lines do not accurately recapitulate the 3D tumor microenvironment, which is especially important in cancer research. While PC cell lines have helped progress the PC research field, they do not reflect the clinical spectrum of PC [62].

To overcome these limitations of the PC cell lines, various in vivo models of tumor propagation have been developed by researchers, including patient-derived xenograft (PDX) models, genetically engineered mouse (GEM) models, and 3D culture of patient-derived PC cells (organoid or sphere culture).

Table 1. Original PC cell lines and their pathological type, origin, prostate-specific antigen (PSA) reactivity, and expression level of androgen receptor (AR) and estrogen receptor (ER).

\begin{tabular}{|c|c|c|c|c|c|c|}
\hline Cell Line & Origin & Type & PSA & AR & $\mathrm{ER}-\alpha, \beta$ & Reference \\
\hline LNCaP & Lymph node metastasis & Adenocarcinoma & + & + & $+\mathrm{ER}-\beta$ & {$[41,42]$} \\
\hline PC-3 & Bone metastasis & Adenocarcinoma & - & - & $\begin{array}{l}+ \text { ER- } \alpha \\
\text { ER- } \beta\end{array}$ & {$[43,44]$} \\
\hline DU145 & Brain metastasis & Adenocarcinoma & - & - & $+\mathrm{ER}-\beta$ & {$[45,46]$} \\
\hline VCap & Xenograft from metastasis & Adenocarcinoma & + & + & $+E R-\beta$ & {$[47,48]$} \\
\hline NCI-H660 & $\begin{array}{l}\text { Metastatic extrapulmonary } \\
\text { small cell carcinoma arising } \\
\text { from the PC }\end{array}$ & Adenocarcinoma & - & - & - & [49] \\
\hline PC346 & Primary tumor xenograft & Adenocarcinoma & + & \pm & - & {$[50]$} \\
\hline $\begin{array}{c}\text { 22Rv1 } \\
\text { (CWR22Rv1) }\end{array}$ & $\begin{array}{c}\text { CRPC derivative of CWR22 } \\
\text { xenograft }\end{array}$ & Adenocarcinoma & + & + & $\begin{array}{l}+ \text { ER- } \alpha \\
\text { ER- } \beta\end{array}$ & [51] \\
\hline CWR22Pc & CWR22 xenograft & Adenocarcinoma & + & + & $+\mathrm{ER}-\beta$ & {$[63,64]$} \\
\hline $\begin{array}{l}\text { MDA PCa 2a \& } \\
\text { MDA PCa 2b }\end{array}$ & Bone metastasis & Adenocarcinoma & + & + & + ER- $\beta$ & {$[53,54]$} \\
\hline KUCaP & $\begin{array}{l}\text { Xenograft from liver } \\
\text { metastasis }\end{array}$ & Adenocarcinoma & + & + & - & [52] \\
\hline
\end{tabular}


Table 2. Sublines derived from PC cell lines and their resistant profile.

\begin{tabular}{ccccc}
\hline Subline & Original Cell Line & Resistance & Established Method & Reference \\
\hline LNCaP-abl & LNCaP & Castration & Culture in ADM & {$[57]$} \\
\hline LNCaP-LTAD & LNCaP & Castration & Culture in ADM & {$[58]$} \\
\hline LNCaP-BicR & LNCaP & Anti-androgens & Culture with flutamide & {$[65]$} \\
\hline PC346Flu1/2 & PC346 & Anti-androgens & $\begin{array}{c}\text { Culture in ADM with } \\
\text { flutamide }\end{array}$ & {$[66]$} \\
\hline PC-3R & PC-3 & Chemotherapy & Docetaxel & {$[67]$} \\
\hline DU145-TxR & DU145 & Chemotherapy & Culture with paclitaxel & {$[68]$} \\
\hline DU145R & DU145 & Chemotherapy & Culture with docetaxel & {$[67]$} \\
\hline PC-3CR & PC-3 & Chemotherapy & Culture with cabazitaxel & {$[69]$} \\
\hline PC-3 D12 & PC-3 & Chemotherapy & Culture with docetaxel & {$[70]$} \\
\hline
\end{tabular}

\subsection{Xenograft Mouse Models}

To date, preclinical PC mouse models continue to be an important gadget to enhance our perception of PC development, proliferation, and metastatic behavior. The incidence of spontaneous PC in mice is rare [71]. Therefore, several tumor-xenografted or genetically engineered PC mouse models have been developed [72] (Figure 1). Among them, xenograft models have been emerged and generated through heterotopic or orthotopic [73] implantation of human tumor tissues, primary cell cultures, or cell lines [74], in nude mice [75], SCID [76], NOD-SCID [77], NOG/NSG [78], or RAG [79].

Compared with cell lines, patient-derived xenografts (PDXs) may more properly recapitulate the molecular divergence and cellular heterogeneity of tumors of patients [80,81]. The PDXs of PC were easily developed, characterized [82,83], and shown to be beneficial in anti-cancer drugs screening for efficacy and toxicity $[84,85]$. Xenografting of patient-derived PC cells was improved by using chimeric grafts with neonatal mouse mesenchyme [86] and by establishing highly immunodeficient mice such as NOG (NOD/Scid/IL2R $\left.\gamma^{\text {null }}\right)$, NSG (NOD/Scid/IL2R $\left.\gamma^{\text {null }}\right)$, and NOJ (NOD/Scid/Jak3 $\left.{ }^{\text {null }}\right)$ mice [87].

Several PDX models are established by directly xenografting patient-derived tissues into immunodeficient mice. The first of which has been demonstrated by Gittes in 1980 in athymic nude mice and maintained many of the histological characteristics of human PC [88]. Later, numerous models were established, as reviewed in [89]. For example, the Rotterdam PC xenograft models were generated from primary prostatectomy specimens, transurethral resection specimens, and metastatic lesions $[50,75,90]$, and the established xenografts retained the histological structure of their original patient tumors. Another model is the LuCaP PDX model which was established from primary PC tumors or PC metastases $[84,91]$ and showed the main genomic and phenotypic characters of their original tumors, including Phosphatase and tensin homolog (PTEN) deletion, AR amplification, TP53 deletion and mutation, Transmembrane protease, serine (TMPRSS)-Erythroblast transformation-specific-related gene (ERG) rearrangement, RB1 loss, SPOP mutation, and BRCA2 loss.

Despite the beneficial outcomes from using mice in xenograft studies, the heterogeneity of mouse tissues regarding the cancer stem cell (CSC) niche and stromal compartment of the prostate [92] compared with human and immunodeficiency state are major limitations [81]. Additionally, different murine physiology and response to therapeutic agents are also other potential limitations. Moreover, a drug screening using xenograft model mice usually takes several months and costs a lot of money. Therefore, it is not amenable to high-throughput screening [93].

\subsection{Organoid Culture of Patient-Derived PC Cells}

Because of the limitations of cell lines and PDXs, 3D cell culture systems (known as organoids) are getting great attention as patient-derived cancer models. Organoids are mini organ-like structures with important organ features. It is frequently used as an intermediate model between in vitro cancer cell lines and PDXs. Organoids can efficiently and closely recapitulate the in vivo microenvironment as 
well as molecular and genetic signature of tissues or organs of origin and are capable of self-renewal and self-organization [94-97]. It also could provide the benefit for cancer-related studies, disease modeling, drug discovery, and personalized therapy [95,98-103]. The microenvironment, particularly the extracellular matrix, in which the organoids are grown, strongly influences their cellular behavior [104].

In addition to the primary 3D organoid culture system, numerous 3D culture model systems have been established to simulate the in vitro structural connections between epithelial cells and stroma and to model organ development and function [105]. These systems are derived from cell lines, primary tissues, embryonic stem cells, and induced pluripotent stem cells (iPS cells) [105] (Figure 2).

\subsubsection{PC Organoids for Screening of Gene Mutations}

The incidence of genomic instability is one of the hallmarks of cancer [106,107]. Consequently, cancer cells typically contain numerous mutations, which widely differ among and within different types of cancers [108]. Interestingly, only a few of these mutations (driver mutations), drive the disease progression [107]. Hence, organoids can maintain the genetic and phenotypic landscape of the original tumor and are more suited for in vitro manipulations. Therefore, they were efficiently used to identify the driver mutations of the original tumors [109]. Additionally, organoids can be genetically handled using CRISPR/Cas9 and shRNA systems rendering the organoid culture an attractive platform for rapid examination of the impact of genotypes and mutational signature on pharmacological responses [110].

The organoids from the primary advanced or castration-resistant PC tissues or PDXs were successfully shown to recapitulate several genetic mutations of the disease (Figure 3). Next-generation sequencing of the exome and genome of PC has recognized several genetic mutations. Among them, SPOP is one of the most frequently mutated genes in primary PC, suggesting that SPOP may be a potential driver of PC [111]. In mouse PC organoids, mutation of the SPOP gene led to increased proliferation and a transcriptional signature consistent with human PC.

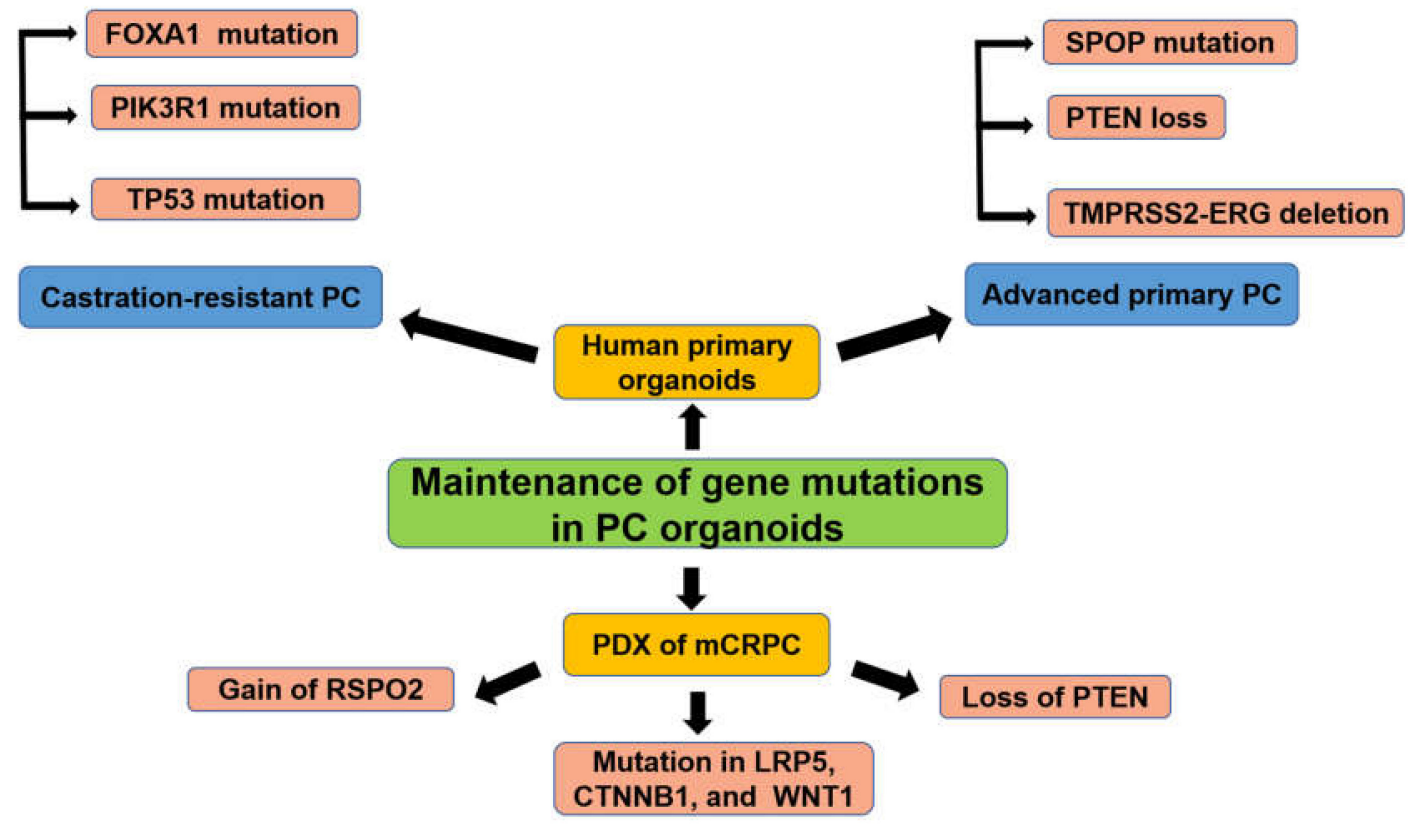

Figure 3. PC organoids for gene mutation screening. FOXA1: Forkhead box protein A1; PIK3R1: Phosphoinositide-3-kinase regulatory subunit 1; TP53: Total protein 53; SPOP: Speckle-type POZ protein; PTEN: Phosphatase and tensin homolog; TMPRESS2: Transmembrane protease, serine 2; ERG: Erythroblast transformation-specific-related gene; RSPO2: R-spondin 2; LRP5: Low-density lipoprotein receptor-related protein 5; CTNNB1: Catenin beta 1; WNT1: Wingless-type MMTV integration site family, member 1. 
Recently, normal human and mouse prostate organoids have been developed, which can be cultured indefinitely without immortalization and can recapitulate the normal prostate glandular structure [110]. This system has been optimized for human advanced and metastatic PC specimens and 7 new organoids lines have been successfully established (six from biopsy samples and one from circulating tumor cells). After 3 months of in vitro culture, this system clearly demonstrated the previously identified frequent genetic mutations shown in advanced primary PC including PTEN loss, SPOP mutation, TMPRSS2-ERG interstitial deletion, as well as mCRPC involving Phosphoinositide-3-kinase regulatory subunit 1 (PIK3R1), TP53, FOXA1, and several mutations in chromatin modifier [112]. In another study, PC organoids generated from PDXs of mCRPC successfully recapitulated and conserved the genetic and phenotypic heterogeneity such as copy number variations including gains at chromosome $8 q$ and losses at $8 p$ and 13q [113]. Moreover, gain of R-spondin (RSPO)2, loss of PTEN, and a somatic coding mutation in Low-density lipoprotein receptor-related protein (LRP)5, Catenin beta (CTNNB)1, and Wingless-type MMTV integration site family, member (WNT)1 were also recorded [113]. Importantly, these lineage markers and transcriptomes were maintained from PDXs to the organoids even after the late generation [113].

Analysis of PC organoids showed that ERG was an effector of SPOP mutation in human and mouse PC models [114]. The analysis also revealed that BAF complexes were necessary for ERG-triggered basal-to-luminal transition, a typical feature of ERG activity in PC [115]. Mutation in the SPOP gene was shown to enhance the proliferation of PC cells by promoting ubiquitination and turnover of c-Myc oncoprotein as the organoid-forming capacity of SPOP-null murine prostate cells was more sensitive to c-Myc inhibition [116]. In another study, SPOP mutant organoids demonstrated a higher formation capability with more irregular borders and increased Ki-67 expression without AR upregulation compared with control ones [117]. Furthermore, it drove the in vivo tumorigenesis by regulation of PI3K/mTOR and AR signaling [117].

Loss of the chromatin remodeler chromodomain helicase DNA-binding protein 1 (CHD1) is a major genomic change found in human local and metastatic PC [118] and represents a distinct PC subtype characterized by SPOP mutation [119]. High levels of chromosomal rearrangements and higher genomic instability are associated with a potential defect in DNA damage repair $[60,120]$. Shenoy et al. revealed the role of CHD1 in PC development by using the CHD1-deleted mouse model and patient-derived organoid culture [121]. Collectively, these data suggest the efficiency of PC organoid models in studying and screening of genetic mutations in PC.

\subsubsection{PC Organoids for Predicting Anti-Cancer Drugs Sensitivity or Resistance}

In PC, patient-derived organoids can provide preclinical models to perceive the precision medicine by drug screening of individual patient samples [24] (Figure 4). The ability to identify agents with high clinical effectiveness prior to clinical trials would enhance the efficiency of translating preclinical research into clinical practice.

Several established PC organoids from humans, mice, and dogs were successfully used to assess drug response. In humans, the seven established organoid lines by Gao et al., [112] were used for in vitro and in vivo screening of anti-cancer drugs. This 3D model was used for evaluation of the efficacy of three anti-cancer drugs, enzalutamide (the next-generation antiandrogen) and two phosphoinositide 3 kinase pathway inhibitors, everolimus, and BKM-120, which were used in clinical trials to treat a castration-resistant PC [112]. Data revealed that only one organoid line (MSK-PCa2, which harbors an AR amplification, PIK3R1 mutation, and PTEN loss) showed high sensitivity to enzalutamide, which supports the conclusion that molecular subtyping is necessary for targeting therapy [122]. Amazingly, this sensitive organoid line has demonstrated the same outcomes as a xenograft mouse model.

In the same study, the organoid line established from PC circulating tumor cells instead of a core biopsy of metastatic sites is a distinct clinical possibility and is valuable as an efficacy-response indicator for overall survival in MCRPC [123]. The advantage of this model is to guide targeted 
therapy when access to tissue biopsy is impossible, as the case in bone marrow lesions of patients with metastatic PC.

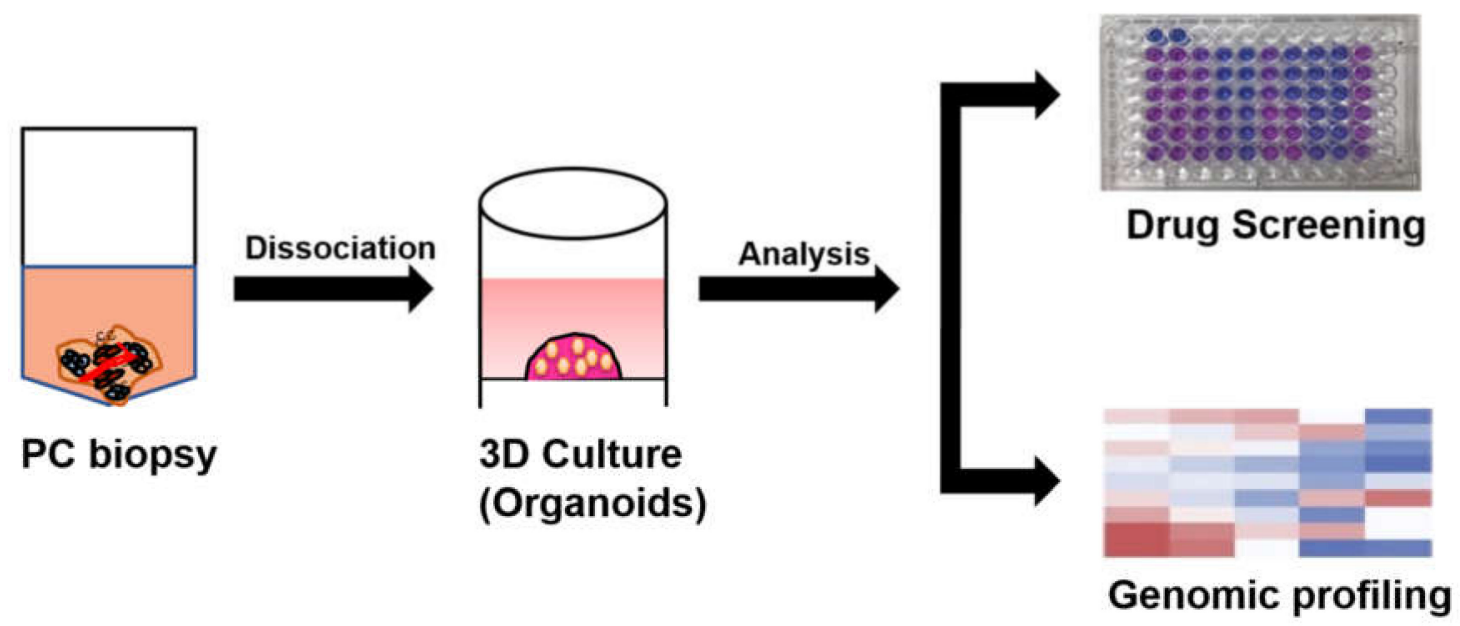

Figure 4. PC organoids for drug screening. After the biopsy samples are mechanically minced and enzymatically digested, the cell suspension is strained, washed and embedded within Matrigel to form organoids. After serial passaging, the 3D organoids can be used for drug screening as well as genomic profiling.

In another study, Beshiri et al., found the sensitivity of PC organoids generated from PDXs of metastatic castrate-resistant PC to the PARP inhibitor, olaparib was similar to the responses recorded clinically in the patients [113].

The mutation in SPOP gene plays a role in the response of PC organoids to anti-cancer drugs. The PC organoids expressing SPOP W131R mutation are resistant to intrinsic BET inhibitors-induced cell growth arrest and apoptosis due to the stabilization of BET protein and activation of AKT-mTORC1 signaling [124-126]. To overcome this resistance, Yan et al. have investigated the anti-cancer effects of NEO2734 (novel BET-CBP/p300 dual inhibitor) in SPOP-mutated organoids from PC patients [127]. They demonstrated that NEO2734 showed the effectiveness in BET inhibitor (JQ1)-resistant SPOP mutant PC organoids [127].

In the mouse PC model, Chua et al., [128] assessed the sensitivity to anti-cancer drugs, using PC organoids generated from Nkx3.1 ${ }^{\text {CreERT2/+ }}$; Pten ${ }^{\text {flox/flox }}$; R26R-YFP/ + (NP) mice, which were previously used to screen therapeutic response in vivo [129]. Despite NP mice initially developed castration-sensitive PC, they later develop mCRPC that is responsive to dual treatment with an Akt inhibitor, MK-2206, and an mTOR inhibitor, MK-8669 (ridaforolimus) [129]. Using tamoxifen-induced NP mice, YFP-positive prostate cells were isolated for organoid culture and drug screening. The alone treatment of organoids with AR antagonist, enzalutamide or MK-8669 had minimal effects on organoid formation, while the combined treatment drastically inhibited organoid formation. Interestingly, these data are consistent with the known synergistic activities of AR and PI3K signaling in human PC [130].

In the dog PC model, the established organoids from urine cells also showed different sensitivities to the commonly used anti-cancer drugs [94,97]. The applied cell viability of these organoids revealed no response to a cyclooxygenase (COX)2 inhibitor, piroxicam. However, docetaxel and radiotherapy decreased the cell viability of these organoids in a dose-dependent manner.

\subsubsection{PC Organoids as An Effective Model to Study Mechanisms of Resistance to ADT}

Resistance to anti-cancer drugs is one of the major clinical issues in cancer therapy. Treatment of metastatic PC is primarily directed at the androgen-signaling axis. Next-generation ADT (e.g., abiraterone and enzalutamide) have revealed great clinical success, however, almost all PC ultimately proceed towards an androgen-independent state. 
Recently, transcriptomic and genomic profiling of androgen-independent PC showed three general mechanisms of resistance in PC [131]. The first of which is activating mutations that lead to the restoration of androgen receptor signaling [132]. The second is a stimulation of bypass signaling to escape from androgen receptor blockade, as activation of the glucocorticoid receptor can compensate for the loss of androgen receptor signaling by activating a similar but distinguishable set of target genes necessary for the maintenance of the resistant phenotype [133]. The third is through the process of lineage plasticity, in which cancer cells get resistance by switching lineages from a drug target-dependent cell type to another none dependent one [134].

However, the molecular mechanisms that trigger resistance of PC to anti-cancer drugs are still poorly understood. Furthermore, the acquired resistance to ADT may drive to therapeutic vulnerabilities that can be tackled. Therefore, it is necessary for developing a model system to evaluate drug responses that simulate patient phenotypes and genotypes [131].

Since organoids can be genetically handled using CRISPR/Cas9 and shRNA systems, it can be a promising platform for elucidating the mechanisms of resistance to anti-cancer drugs [110]. Pappas et al., studied the effects of several anti-androgen molecules on PC murine organoids with different genotypes including Wild type (WT) genotype, PTEN loss, TP53 loss, or dual PTEN and TP53 loss [131]. They found that loss of TP53 did not cause resistance to the anti-androgenic molecules. However, loss of PTEN enhanced the resistance to the tested anti-androgens, as demonstrated previously [130]. Furthermore, they showed that dual loss of TP53 and PTEN resulted in complete resistance to the second-generation anti-androgens [131].

It is well known that patient-derived PC organoids are heterogeneous in phenotype and genotype [112,135]. Thus, responses to drugs greatly vary among human PC organoid lines. In the same study carried out by Pappas et al., a growth of MSKPCA2 organoids was substantially inhibited by anti-androgenic molecules. MSKPCA2 organoids expressed high levels of androgen receptor and luminal cell marker (CK8), while MSKPCA3 organoids showed resistance and expressed basal cell marker (CK5) [131].

The study carried out by Beshiri et al., [113] has determined the utility of the PDX-derived organoids as a model of AR-dependence, a cardinal feature of castration-resistant prostate adenocarcinoma. They analyzed the dynamics of AR and AR-responsive gene expression in organoids derived from highly (LuCaP 167) and moderately (LuCaP 77) castration-sensitive PDX models and from an AR-negative neuroendocrine control (LuCaP 145.2). Collectively, these data indicate the usefulness of PC organoids as a promising model to analyze the drug resistance in PC disease.

\subsubsection{PC Organoids to Study Cell of Origin of PC}

Identifying cell of origin of PC might open new insights into the pathogenesis of PC initiation and may drive to better prognosis and selection of convenient therapy $[119,136]$. The cell of origin is the cell inside a normal tissue that subjects to oncogenic transformation to initiate tumor formation [137]. The cell origins of PC are still debated and differ among species and experimental models. The basal cells are considered as cells of origin, while luminal cells are commonly involved by genetic lineage-tracing in GEM models [138].

The 3D culture system of normal prostate organoid has been established and allows the growth and differentiation of both basal and luminal cell types [139]. This leads to establishing numerous models to study the cell of origin of PC [119].

In human PC, the luminal phenotype characterized by atypical glands and an absence of basal cells was observed [140], suggesting that PC originates from luminal cells. In contrast, it was reported that basal cells have the capacity for transformation in human PC $[141,142]$ based on the expression of a number of stem cell markers, including $\alpha 2 \beta 1$ integrin, CD44, and CD133 [143,144].

Oncogenic insults of basal cells can trigger prostate tumorigenesis, suggesting a basal cell origin for mouse and human PC. For example, overexpression of ERG or activated Akt in Lin ${ }^{-} \mathrm{Sca}-1^{+} \mathrm{CD} 49^{\text {hi }}$ basal cells induced prostatic intraepithelial neoplasia, and co-activation of Akt and AR signaling 
produced adenocarcinoma [145]. In another way, overexpression of Myc proto-oncogene protein and activated Akt in human basal cells gave rise to prostatic squamous adenocarcinoma [142].

The bioinformatic analysis revealed the enhanced aggressiveness of PC originated from luminal cells. This analysis could be valuable in the identification of patients who need urgent treatment and those who could benefit from active surveillance. The castration-resistant NKX3-1-expressing stem cells which reside in the luminal layer of an androgen-deprived prostate were shown to be the cell of origin in PC after PTEN deletion and give rise to both basal and luminal cells [146]. Also, organoids generated from CD38-low luminal cells expressing both basal (CK5 and p63) and luminal (CK8) cell markers showed higher organoid formation (4-5 times) and could regenerate into prostatic glands in vivo compared with CD38-high luminal cells, suggesting that it could be a useful biomarker to identify progenitor-like and inflammation-linked luminal cells that can launch human PC [147].

Park and colleagues [148] showed that both primary basal and luminal epithelial cells are cells of origin for PC using the organoid culture system. By overexpression of c-Myc and activated Akt in both cells, they found c-Myc-myrAkt1-transduced luminal xenografts showed well-differentiated acinar adenocarcinoma, whereas the basal xenografts were histologically more aggressive, suggesting that both kinds of cells could respond to the same oncogenic insults to initiate tumorigenesis, but the tumor phenotypes are different [148].

In PC mouse models, current evidence can support both a basal [149-152] and a luminal $[128,146,153]$ CSC model of PC and can initiate PC with heterogeneous molecular signatures that are predictive of human patient outcomes. 3D culture of luminal cells derived from a PTEN-TP53-null mouse model was able to initiate adenocarcinoma or tumors with multilineage histological phenotypes [154].

In the dog PC model, we have established PC organoids from urine-derived CSCs. We showed that the basal cell-sorted organoids grew more efficiently than the luminal cell-sorted ones [94,97]. Moreover, the organoid-forming efficiency of basal cell-sorted organoids was significantly higher and had solid sphere structures compared with that of luminal cell-sorted organoids which had glandular structure. Interestingly, these data correspond with those recorded before in human prostate sorted cell-derived organoids [148], emphasizing the importance of this model in analyzing the cell of origin of PC in human. Compared with human, dogs are known to spontaneously develop PC [155] and have some similarities in the pathogenesis of the disease [156]. Therefore, dog PC may serve as a useful model for the diagnosis and treatment of PC in human.

\section{Conclusions}

Studies about PC have been restrained by the fact that current preclinical PC models do not accurately recapitulate the heterogeneity or complexity of the tissue microenvironment of PC. The advances in the development of organoids have thrilling possibilities for PC studies. The establishment of organoid biobanks and patient-derived organoids can facilitate the promotion of personalized medicine, for example, a high-throughput drug screening for therapeutic and toxic effects to identify the most effective and less toxic therapy for the individual patient. Additionally, an elucidation of the mechanism of drug resistance and a screening of genetic mutations responsible for the disease emergence and progression are now possible using this model. Future studies focusing on PC organoid culture will contribute to understanding the pathogenesis of human PC and identifying the new therapeutic target.

Funding: This research received no external funding.

Conflicts of Interest: The authors declare no conflict of interest. 


\section{References}

1. Siegel, R.L.; Miller, K.D.; Jemal, A. Cancer statistics, 2019. CA A Cancer J. Clin. 2019, 69, 7-34. [CrossRef] [PubMed]

2. Hecht, S.S. Tobacco smoke carcinogens and lung cancer. J. Natl. Cancer Inst. 1999, 91, 1194-1210. [CrossRef] [PubMed]

3. Bullock, T.L.; Andriole, G.L., Jr. Emerging drug therapies for benign prostatic hyperplasia. Expert Opin. Emerg. Drugs 2006, 11, 111-123. [CrossRef] [PubMed]

4. Carlsson, S.V.; Roobol, M.J. Improving the evaluation and diagnosis of clinically significant prostate cancer in 2017. Curr. Opin. Urol. 2017, 27, 198-204. [CrossRef] [PubMed]

5. Fizazi, K.; Tran, N.; Fein, L.; Matsubara, N.; Rodriguez-Antolin, A.; Alekseev, B.Y.; Ozguroglu, M.; Ye, D.; Feyerabend, S.; Protheroe, A.; et al. Abiraterone acetate plus prednisone in patients with newly diagnosed high-risk metastatic castration-sensitive prostate cancer (LATITUDE): Final overall survival analysis of a randomised, double-blind, phase 3 trial. Lancet Oncol. 2019, 20, 686-700. [CrossRef]

6. Maitland, N.J. Stem cells in the normal and malignant prostate. In Prostate Cancer; Tindall, D.J., Ed.; Springer: New York, NY, USA, 2013; pp. 3-41. [CrossRef]

7. Wang, Y.; Hayward, S.; Cao, M.; Thayer, K.; Cunha, G. Cell differentiation lineage in the prostate. Differ. Res. Biol. Divers. 2001, 68, 270-279. [CrossRef]

8. Di Zazzo, E.; Galasso, G.; Giovannelli, P.; Di Donato, M.; Di Santi, A.; Cernera, G.; Rossi, V.; Abbondanza, C.; Moncharmont, B.; Sinisi, A.A.; et al. Prostate cancer stem cells: The role of androgen and estrogen receptors. Oncotarget 2016, 7, 193-208. [CrossRef]

9. Frame, F.M.; Maitland, N.J. Cancer stem cells, models of study and implications of therapy resistance mechanisms. In Human Cell Transformation: Role of Stem Cells and the Microenvironment; Rhim, J.S., Kremer, R., Eds.; Springer: New York, NY, USA, 2012; pp. 105-118.

10. Di Zazzo, E.; Galasso, G.; Giovannelli, P.; Di Donato, M.; Bilancio, A.; Perillo, B.; Sinisi, A.A.; Migliaccio, A.; Castoria, G. Estrogen receptors in epithelial-mesenchymal transition of prostate cancer. Cancers 2019, 1418. [CrossRef]

11. Di Zazzo, E.; Galasso, G.; Giovannelli, P.; Di Donato, M.; Castoria, G. Estrogens and their receptors in prostate cancer: Therapeutic implications. Front. Oncol. 2018, 8, 2. [CrossRef]

12. Claessens, F.; Denayer, S.; Van Tilborgh, N.; Kerkhofs, S.; Helsen, C.; Haelens, A. Diverse roles of androgen receptor (AR) domains in AR-mediated signaling. Nucl. Recept. Signal. 2008, 6, e008. [CrossRef]

13. Cato, A.C.; Nestl, A.; Mink, S. Rapid actions of steroid receptors in cellular signaling pathways. Sci. STKE 2002, 2002, re9. [CrossRef] [PubMed]

14. Giovannelli, P.; Di Donato, M.; Giraldi, T.; Migliaccio, A.; Castoria, G.; Auricchio, F. Targeting rapid action of sex-steroid receptors in breast and prostate cancers. Front. Biosci. 2012, 4, 453-461. [CrossRef]

15. Castoria, G.; Lombardi, M.; Barone, M.V.; Bilancio, A.; Di Domenico, M.; Bottero, D.; Vitale, F.; Migliaccio, A.; Auricchio, F. Androgen-Stimulated DNA synthesis and cytoskeletal changes in fibroblasts by a nontranscriptional receptor action. J. Cell Biol. 2003, 161, 547-556. [CrossRef] [PubMed]

16. Castoria, G.; D'Amato, L.; Ciociola, A.; Giovannelli, P.; Giraldi, T.; Sepe, L.; Paolella, G.; Barone, M.V.; Migliaccio, A.; Auricchio, F. Androgen-induced cell migration: Role of androgen receptor/filamin A association. PLoS ONE 2011, 6, e17218. [CrossRef]

17. Cunha, G.R.; Wang, Y.Z.; Hayward, S.W.; Risbridger, G.P. Estrogenic effects on prostatic differentiation and carcinogenesis. Reprod. Fertil. Dev. 2001, 13, 285-296. [CrossRef]

18. Hu, W.Y.; Shi, G.B.; Lam, H.M.; Hu, D.P.; Ho, S.M.; Madueke, I.C.; Kajdacsy-Balla, A.; Prins, G.S. Estrogen-Initiated transformation of prostate epithelium derived from normal human prostate stem-progenitor cells. Endocrinology 2011, 152, 2150-2163. [CrossRef]

19. Migliaccio, A.; Castoria, G.; Di Domenico, M.; de Falco, A.; Bilancio, A.; Lombardi, M.; Barone, M.V.; Ametrano, D.; Zannini, M.S.; Abbondanza, C.; et al. Steroid-Induced androgen receptor-oestradiol receptor beta-Src complex triggers prostate cancer cell proliferation. EMBO J. 2000, 19, 5406-5417. [CrossRef]

20. Grisanzio, C.; Signoretti, S. p63 in prostate biology and pathology. J. Cell. Biochem. 2008, 103, $1354-1368$. [CrossRef]

21. Berry, P.A.; Maitland, N.J.; Collins, A.T. Androgen receptor signalling in prostate: Effects of stromal factors on normal and cancer stem cells. Mol. Cell. Endocrinol. 2008, 288, 30-37. [CrossRef] 
22. Elbadawy, M.; Usui, T.; Mori, T.; Tsunedomi, R.; Hazama, S.; Nabeta, R.; Uchide, T.; Fukushima, R.; Yoshida, T.; Shibutani, M.; et al. Establishment of a novel experimental model for muscle-invasive bladder cancer using a dog bladder cancer organoid culture. Cancer Sci. 2019, 110, 2806-2821. [CrossRef]

23. Elbadawy, M.; Yamanaka, M.; Goto, Y.; Hayashi, K.; Tsunedomi, R.; Hazama, S.; Nagano, H.; Yoshida, T.; Shibutani, M.; Ichikawa, R.; et al. Efficacy of primary liver organoid culture from different stages of non-alcoholic steatohepatitis (NASH) mouse model. Biomaterials 2020, 237, 119823. [CrossRef] [PubMed]

24. Wang, S.; Gao, D.; Chen, Y. The potential of organoids in urological cancer research. Nat. Rev. Urol. 2017, 14, 401-414. [CrossRef] [PubMed]

25. Sanda, M.G.; Cadeddu, J.A.; Kirkby, E.; Chen, R.C.; Crispino, T.; Fontanarosa, J.; Freedland, S.J.; Greene, K.; Klotz, L.H.; Makarov, D.V.; et al. Clinically localized prostate cancer: AUA/ASTRO/SUO guideline. Part II: Recommended approaches and details of specific care options. J. Urol. 2018, 199, 990-997. [CrossRef]

26. Paller, C.J.; Antonarakis, E.S.; Eisenberger, M.A.; Carducci, M.A. Management of patients with biochemical recurrence after local therapy for prostate cancer. Hematol. Oncol. Clin. N. Am. 2013, 27, 1205-1219. [CrossRef] [PubMed]

27. Alemozaffar, M.; Regan, M.M.; Cooperberg, M.R.; Wei, J.T.; Michalski, J.M.; Sandler, H.M.; Hembroff, L.; Sadetsky, N.; Saigal, C.S.; Litwin, M.S.; et al. Prediction of erectile function following treatment for prostate cancer. JAMA 2011, 306, 1205-1214. [CrossRef] [PubMed]

28. Mullins, B.T.; Basak, R.; Broughman, J.R.; Chen, R.C. Patient-Reported sexual quality of life after different types of radical prostatectomy and radiotherapy: Analysis of a population-based prospective cohort. Cancer 2019, 125, 3657-3665. [CrossRef]

29. Resnick, M.J.; Koyama, T.; Fan, K.H.; Albertsen, P.C.; Goodman, M.; Hamilton, A.S.; Hoffman, R.M.; Potosky, A.L.; Stanford, J.L.; Stroup, A.M.; et al. Long-Term functional outcomes after treatment for localized prostate cancer. N. Engl. J. Med. 2013, 368, 436-445. [CrossRef]

30. Venturini, N.J.; Drake, C.G. Immunotherapy for prostate cancer. Cold Spring Harb. Perspect. Med. $2019,9$. [CrossRef]

31. Fizazi, K.; Tran, N.; Fein, L.; Matsubara, N.; Rodriguez-Antolin, A.; Alekseev, B.Y.; Ozguroglu, M.; Ye, D.; Feyerabend, S.; Protheroe, A.; et al. Abiraterone plus prednisone in metastatic, castration-sensitive prostate cancer. N. Engl. J. Med. 2017, 377, 352-360. [CrossRef]

32. James, N.D.; de Bono, J.S.; Spears, M.R.; Clarke, N.W.; Mason, M.D.; Dearnaley, D.P.; Ritchie, A.W.S.; Amos, C.L.; Gilson, C.; Jones, R.J.; et al. Abiraterone for prostate cancer not previously treated with hormone therapy. N. Engl. J. Med. 2017, 377, 338-351. [CrossRef] [PubMed]

33. Scher, H.I.; Morris, M.J.; Stadler, W.M.; Higano, C.; Basch, E.; Fizazi, K.; Antonarakis, E.S.; Beer, T.M.; Carducci, M.A.; Chi, K.N.; et al. Trial design and objectives for castration-resistant prostate cancer: Updated recommendations from the prostate cancer clinical trials working group 3. J. Clin. Oncol. Off. J. Am. Soc. Clin. Oncol. 2016, 34, 1402-1418. [CrossRef]

34. Lau, K.M.; To, K.F. Importance of estrogenic signaling and its mediated receptors in prostate cancer. Int. J. Mol. Sci. 2016, 1434. [CrossRef] [PubMed]

35. Boettcher, A.N.; Usman, A.; Morgans, A.; VanderWeele, D.J.; Sosman, J.; Wu, J.D. Past, current, and future of immunotherapies for prostate cancer. Front. Oncol. 2019, 9, 884. [CrossRef] [PubMed]

36. Topalian, S.L.; Drake, C.G.; Pardoll, D.M. Immune checkpoint blockade: A common denominator approach to cancer therapy. Cancer Cell 2015, 27, 450-461. [CrossRef] [PubMed]

37. Drake, C.G.; Lipson, E.J.; Brahmer, J.R. Breathing new life into immunotherapy: Review of melanoma, lung and kidney cancer. Nat. Rev. Clin. Oncol. 2014, 11, 24-37. [CrossRef] [PubMed]

38. Barretina, J.; Caponigro, G.; Stransky, N.; Venkatesan, K.; Margolin, A.A.; Kim, S.; Wilson, C.J.; Lehar, J.; Kryukov, G.V.; Sonkin, D.; et al. The cancer cell line encyclopedia enables predictive modelling of anticancer drug sensitivity. Nature 2012, 483, 603-607. [CrossRef] [PubMed]

39. Garnett, M.J.; Edelman, E.J.; Heidorn, S.J.; Greenman, C.D.; Dastur, A.; Lau, K.W.; Greninger, P.; Thompson, I.R.; Luo, X.; Soares, J.; et al. Systematic identification of genomic markers of drug sensitivity in cancer cells. Nature 2012, 483, 570-575. [CrossRef]

40. Solit, D.B.; Garraway, L.A.; Pratilas, C.A.; Sawai, A.; Getz, G.; Basso, A.; Ye, Q.; Lobo, J.M.; She, Y.; Osman, I.; et al. BRAF mutation predicts sensitivity to MEK inhibition. Nature 2006, 439, 358-362. [CrossRef] 
41. Horoszewicz, J.S.; Leong, S.S.; Chu, T.M.; Wajsman, Z.L.; Friedman, M.; Papsidero, L.; Kim, U.; Chai, L.S.; Kakati, S.; Arya, S.K.; et al. The LNCaP cell line-A new model for studies on human prostatic carcinoma. Prog. Clin. Biol. Res. 1980, 37, 115-132.

42. Horoszewicz, J.S.; Leong, S.S.; Kawinski, E.; Karr, J.P.; Rosenthal, H.; Chu, T.M.; Mirand, E.A.; Murphy, G.P. LNCaP model of human prostatic carcinoma. Cancer Res. 1983, 43, 1809-1818.

43. Kaighn, M.E.; Narayan, K.S.; Ohnuki, Y.; Lechner, J.F.; Jones, L.W. Establishment and characterization of a human prostatic carcinoma cell line (PC-3). Investig. Urol. 1979, 17, 16-23.

44. Wang, M.; Stearns, M.E. Isolation and characterization of PC-3 human prostatic tumor sublines which preferentially metastasize to select organs in S.C.I.D. mice. Differ. Res. Biol. Divers. 1991, 48, 115-125. [CrossRef] [PubMed]

45. Mickey, D.D.; Stone, K.R.; Wunderli, H.; Mickey, G.H.; Vollmer, R.T.; Paulson, D.F. Heterotransplantation of a human prostatic adenocarcinoma cell line in nude mice. Cancer Res. 1977, 37, 4049-4058. [PubMed]

46. Stone, K.R.; Mickey, D.D.; Wunderli, H.; Mickey, G.H.; Paulson, D.F. Isolation of a human prostate carcinoma cell line (DU 145). Int. J. Cancer 1978, 21, 274-281. [CrossRef] [PubMed]

47. Rubin, M.A.; Putzi, M.; Mucci, N.; Smith, D.C.; Wojno, K.; Korenchuk, S.; Pienta, K.J. Rapid (“warm”) autopsy study for procurement of metastatic prostate cancer. Clin. Cancer Res. Off. J. Am. Assoc. Cancer Res. 2000, 6, 1038-1045.

48. Korenchuk, S.; Lehr, J.E.; MCLean, L.; Lee, Y.G.; Whitney, S.; Vessella, R.; Lin, D.L.; Pienta, K.J. VCaP, a cell-based model system of human prostate cancer. Vivo 2001, 15, 163-168.

49. Mertz, K.D.; Setlur, S.R.; Dhanasekaran, S.M.; Demichelis, F.; Perner, S.; Tomlins, S.; Tchinda, J.; Laxman, B.; Vessella, R.L.; Beroukhim, R.; et al. Molecular characterization of TMPRSS2-ERG gene fusion in the NCI-H660 prostate cancer cell line: A new perspective for an old model. Neoplasia 2007, 9, 200-206. [CrossRef]

50. Marques, R.B.; van Weerden, W.M.; Erkens-Schulze, S.; de Ridder, C.M.; Bangma, C.H.; Trapman, J.; Jenster, G. The human PC346 xenograft and cell line panel: A model system for prostate cancer progression. Eur. Urol. 2006, 49, 245-257. [CrossRef]

51. Sramkoski, R.M.; Pretlow, T.G., II; Giaconia, J.M.; Pretlow, T.P.; Schwartz, S.; Sy, M.S.; Marengo, S.R.; Rhim, J.S.; Zhang, D.; Jacobberger, J.W. A new human prostate carcinoma cell line, 22Rv1. In Vitro Cell. Dev. Biol. Anim. 1999, 35, 403-409. [CrossRef]

52. Yoshida, T.; Kinoshita, H.; Segawa, T.; Nakamura, E.; Inoue, T.; Shimizu, Y.; Kamoto, T.; Ogawa, O. Antiandrogen bicalutamide promotes tumor growth in a novel androgen-dependent prostate cancer xenograft model derived from a bicalutamide-treated patient. Cancer Res. 2005, 65, 9611-9616. [CrossRef]

53. Navone, N.M.; Olive, M.; Ozen, M.; Davis, R.; Troncoso, P.; Tu, S.M.; Johnston, D.; Pollack, A.; Pathak, S.; von Eschenbach, A.C.; et al. Establishment of two human prostate cancer cell lines derived from a single bone metastasis. Clin. Cancer Res. Off. J. Am. Assoc. Cancer Res. 1997, 3, 2493-2500.

54. Zhao, X.Y.; Boyle, B.; Krishnan, A.V.; Navone, N.M.; Peehl, D.M.; Feldman, D. Two mutations identified in the androgen receptor of the new human prostate cancer cell line MDA PCa 2a. J. Urol. 1999, 162, 2192-2199. [CrossRef]

55. Leister, P.; Felten, A.; Chasan, A.I.; Scheidtmann, K.H. ZIP kinase plays a crucial role in androgen receptor-mediated transcription. Oncogene 2008, 27, 3292-3300. [CrossRef] [PubMed]

56. Elbadawy, M.; Usui, T.; Yamawaki, H.; Sasaki, K. novel functions of death-associated protein kinases through mitogen-activated protein kinase-related signals. Int. J. Mol. Sci. 2018, 19, 3031. [CrossRef] [PubMed]

57. Culig, Z.; Hoffmann, J.; Erdel, M.; Eder, I.E.; Hobisch, A.; Hittmair, A.; Bartsch, G.; Utermann, G.; Schneider, M.R.; Parczyk, K.; et al. Switch from antagonist to agonist of the androgen receptor bicalutamide is associated with prostate tumour progression in a new model system. Br. J. Cancer 1999, 81, $242-251$. [CrossRef]

58. Takayama, K.; Horie-Inoue, K.; Suzuki, T.; Urano, T.; Ikeda, K.; Fujimura, T.; Takahashi, S.; Homma, Y.; Ouchi, Y.; Inoue, S. TACC2 is an androgen-responsive cell cycle regulator promoting androgen-mediated and castration-resistant growth of prostate cancer. Mol. Endocrinol. 2012, 26, 748-761. [CrossRef]

59. Taylor, B.S.; Schultz, N.; Hieronymus, H.; Gopalan, A.; Xiao, Y.; Carver, B.S.; Arora, V.K.; Kaushik, P.; Cerami, E.; Reva, B.; et al. Integrative genomic profiling of human prostate cancer. Cancer Cell 2010, 18, 11-22. [CrossRef] 
60. Baca, S.C.; Prandi, D.; Lawrence, M.S.; Mosquera, J.M.; Romanel, A.; Drier, Y.; Park, K.; Kitabayashi, N.; MacDonald, T.Y.; Ghandi, M.; et al. Punctuated evolution of prostate cancer genomes. Cell 2013, 153, 666-677. [CrossRef]

61. Barbieri, C.E.; Baca, S.C.; Lawrence, M.S.; Demichelis, F.; Blattner, M.; Theurillat, J.P.; White, T.A.; Stojanov, P.; Van Allen, E.; Stransky, N.; et al. Exome sequencing identifies recurrent SPOP, FOXA1 and MED12 mutations in prostate cancer. Nat. Genet. 2012, 44, 685-689. [CrossRef]

62. Vela, I.; Chen, Y. Prostate cancer organoids: A potential new tool for testing drug sensitivity. Expert Rev. Anticancer 2015, 15, 261-263. [CrossRef]

63. Pretlow, T.G.; Wolman, S.R.; Micale, M.A.; Pelley, R.J.; Kursh, E.D.; Resnick, M.I.; Bodner, D.R.; Jacobberger, J.W.; Delmoro, C.M.; Giaconia, J.M.; et al. Xenografts of primary human prostatic carcinoma. J. Natl. Cancer Inst. 1993, 85, 394-398. [CrossRef] [PubMed]

64. Dagvadorj, A.; Tan, S.H.; Liao, Z.; Cavalli, L.R.; Haddad, B.R.; Nevalainen, M.T. Androgen-Regulated and highly tumorigenic human prostate cancer cell line established from a transplantable primary CWR22 tumor. Clin. Cancer Res. Off. J. Am. Assoc. Cancer Res. 2008, 14, 6062-6072. [CrossRef] [PubMed]

65. Takayama, K.; Misawa, A.; Suzuki, T.; Takagi, K.; Hayashizaki, Y.; Fujimura, T.; Homma, Y.; Takahashi, S.; Urano, T.; Inoue, S. TET2 repression by androgen hormone regulates global hydroxymethylation status and prostate cancer progression. Nat. Commun. 2015, 6, 8219. [CrossRef] [PubMed]

66. Marques, R.B.; Dits, N.F.; Erkens-Schulze, S.; van Ijcken, W.F.; van Weerden, W.M.; Jenster, G. Modulation of androgen receptor signaling in hormonal therapy-resistant prostate cancer cell lines. PLoS ONE 2011,6, e23144. [CrossRef] [PubMed]

67. Marin-Aguilera, M.; Codony-Servat, J.; Kalko, S.G.; Fernandez, P.L.; Bermudo, R.; Buxo, E.; Ribal, M.J.; Gascon, P.; Mellado, B. Identification of docetaxel resistance genes in castration-resistant prostate cancer. Mol. Cancer Ther. 2012, 11, 329-339. [CrossRef]

68. Takeda, M.; Mizokami, A.; Mamiya, K.; Li, Y.Q.; Zhang, J.; Keller, E.T.; Namiki, M. The establishment of two paclitaxel-resistant prostate cancer cell lines and the mechanisms of paclitaxel resistance with two cell lines. Prostate 2007, 67, 955-967. [CrossRef]

69. Hongo, H.; Kosaka, T.; Oya, M. Analysis of cabazitaxel-resistant mechanism in human castration-resistant prostate cancer. Cancer Sci. 2018, 109, 2937-2945. [CrossRef]

70. O'Neill, A.J.; Prencipe, M.; Dowling, C.; Fan, Y.; Mulrane, L.; Gallagher, W.M.; O'Connor, D.; O'Connor, R.; Devery, A.; Corcoran, C.; et al. Characterisation and manipulation of docetaxel resistant prostate cancer cell lines. Mol. Cancer 2011, 10, 126. [CrossRef]

71. Shappell, S.B.; Thomas, G.V.; Roberts, R.L.; Herbert, R.; Ittmann, M.M.; Rubin, M.A.; Humphrey, P.A.; Sundberg, J.P.; Rozengurt, N.; Barrios, R.; et al. Prostate pathology of genetically engineered mice: Definitions and classification. The consensus report from the Bar Harbor meeting of the mouse models of Human Cancer Consortium Prostate Pathology Committee. Cancer Res. 2004, 64, 2270-2305. [CrossRef]

72. Rea, D.; Del Vecchio, V.; Palma, G.; Barbieri, A.; Falco, M.; Luciano, A.; De Biase, D.; Perdonà, S.; Facchini, G.; Arra, C. Mouse models in prostate cancer translational research: From xenograft to PDX. Biomed. Res. Int. 2016, 2016, 9750795. [CrossRef]

73. Pettaway, C.A.; Pathak, S.; Greene, G.; Ramirez, E.; Wilson, M.R.; Killion, J.J.; Fidler, I.J. Selection of highly metastatic variants of different human prostatic carcinomas using orthotopic implantation in nude mice. Clin. Cancer Res. Off. J. Am. Assoc. Cancer Res. 1996, 2, 1627-1636.

74. Veldscholte, J.; Ris-Stalpers, C.; Kuiper, G.G.; Jenster, G.; Berrevoets, C.; Claassen, E.; van Rooij, H.C.; Trapman, J.; Brinkmann, A.O.; Mulder, E. A mutation in the ligand binding domain of the androgen receptor of human LNCaP cells affects steroid binding characteristics and response to anti-androgens. Biochem. Biophys. Res. Commun. 1990, 173, 534-540. [CrossRef]

75. Van Weerden, W.M.; de Ridder, C.M.; Verdaasdonk, C.L.; Romijn, J.C.; van der Kwast, T.H.; Schroder, F.H.; van Steenbrugge, G.J. Development of seven new human prostate tumor xenograft models and their histopathological characterization. Am. J. Pathol. 1996, 149, 1055-1062. [PubMed]

76. Craft, N.; Shostak, Y.; Carey, M.; Sawyers, C.L. A mechanism for hormone-independent prostate cancer through modulation of androgen receptor signaling by the HER-2/neu tyrosine kinase. Nat. Med. 1999, 5, 280-285. [CrossRef]

77. Nemeth, J.A.; Harb, J.F.; Barroso, U., Jr.; He, Z.; Grignon, D.J.; Cher, M.L. Severe combined immunodeficient-hu model of human prostate cancer metastasis to human bone. Cancer Res. 1999, 59, 1987-1993. 
78. D'Antonio, J.M.; Vander Griend, D.J.; Antony, L.; Ndikuyeze, G.; Dalrymple, S.L.; Koochekpour, S.; Isaacs, J.T. Loss of androgen receptor-dependent growth suppression by prostate cancer cells can occur independently from acquiring oncogenic addiction to androgen receptor signaling. PLoS ONE 2010, 5, e11475. [CrossRef]

79. Zhang, Q.; Yang, X.J.; Kundu, S.D.; Pins, M.; Javonovic, B.; Meyer, R.; Kim, S.J.; Greenberg, N.M.; Kuzel, T.; Meagher, R.; et al. Blockade of transforming growth factor-\{beta\} signaling in tumor-reactive CD8(+) T cells activates the antitumor immune response cycle. Mol. Cancer Ther. 2006, 5, 1733-1743. [CrossRef]

80. Kopetz, S.; Lemos, R.; Powis, G. The promise of patient-derived xenografts: The best laid plans of mice and men. Clin. Cancer Res. Off. J. Am. Assoc. Cancer Res. 2012, 18, 5160-5162. [CrossRef]

81. Shen, M.M.; Abate-Shen, C. Molecular genetics of prostate cancer: New prospects for old challenges. Genes Dev. 2010, 24, 1967-2000. [CrossRef]

82. Wang, Y.; Revelo, M.P.; Sudilovsky, D.; Cao, M.; Chen, W.G.; Goetz, L.; Xue, H.; Sadar, M.; Shappell, S.B.; Cunha, G.R.; et al. Development and characterization of efficient xenograft models for benign and malignant human prostate tissue. Prostate 2005, 64, 149-159. [CrossRef]

83. Russell, P.J.; Russell, P.; Rudduck, C.; Tse, B.W.; Williams, E.D.; Raghavan, D. Establishing prostate cancer patient derived xenografts: Lessons learned from older studies. Prostate 2015, 75, 628-636. [CrossRef] [PubMed]

84. Nguyen, H.M.; Vessella, R.L.; Morrissey, C.; Brown, L.G.; Coleman, I.M.; Higano, C.S.; Mostaghel, E.A.; Zhang, X.; True, L.D.; Lam, H.M.; et al. LuCaP prostate cancer patient-derived xenografts reflect the molecular heterogeneity of advanced disease an-D serve as models for evaluating cancer therapeutics. Prostate 2017, 77, 654-671. [CrossRef] [PubMed]

85. Navone, N.M.; van Weerden, W.M.; Vessella, R.L.; Williams, E.D.; Wang, Y.; Isaacs, J.T.; Nguyen, H.M.; Culig, Z.; van der Pluijm, G.; Rentsch, C.A.; et al. Movember GAP1 PDX project: An international collection of serially transplantable prostate cancer patient-derived xenograft (PDX) models. Prostate 2018, 78, 1262-1282. [CrossRef] [PubMed]

86. Toivanen, R.; Berman, D.M.; Wang, H.; Pedersen, J.; Frydenberg, M.; Meeker, A.K.; Ellem, S.J.; Risbridger, G.P.; Taylor, R.A. Brief report: A bioassay to identify primary human prostate cancer repopulating cells. Stem Cells 2011, 29, 1310-1314. [CrossRef] [PubMed]

87. Okada, S.; Vaeteewoottacharn, K.; Kariya, R. Establishment of a patient-derived tumor xenograft model and application for precision cancer medicine. Chem. Pharm. Bull. 2018, 66, 225-230. [CrossRef]

88. Gittes, R.F. The nude mouse-Its use as tumor-bearing model of the prostate. Prog. Clin. Biol. Res. 1980, 37, 31-37.

89. Namekawa, T.; Ikeda, K.; Horie-Inoue, K.; Inoue, S. Application of prostate cancer models for preclinical study: Advantages and limitations of cell lines, patient-derived xenografts, and three-dimensional culture of patient-derived cells. Cells 2019, 8, 74. [CrossRef]

90. Van Weerden, W.M.; Bangma, C.; de Wit, R. Human xenograft models as useful tools to assess the potential of novel therapeutics in prostate cancer. Br. J. Cancer 2009, 100, 13-18. [CrossRef]

91. Corey, E.; Quinn, J.E.; Buhler, K.R.; Nelson, P.S.; Macoska, J.A.; True, L.D.; Vessella, R.L. LuCaP 35: A new model of prostate cancer progression to androgen independence. Prostate 2003, 55, 239-246. [CrossRef]

92. Tuxhorn, J.A.; McAlhany, S.J.; Dang, T.D.; Ayala, G.E.; Rowley, D.R. Stromal cells promote angiogenesis and growth of human prostate tumors in a differential reactive stroma (DRS) xenograft model. Cancer Res. 2002, 62, 3298-3307.

93. Gao, D.; Chen, Y. Organoid development in cancer genome discovery. Curr. Opin. Genet. Dev. 2015, 30, 42-48. [CrossRef]

94. Usui, T.; Sakurai, M.; Nishikawa, S.; Umata, K.; Nemoto, Y.; Haraguchi, T.; Itamoto, K.; Mizuno, T.; Noguchi, S.; Mori, T.; et al. Establishment of a dog primary prostate cancer organoid using the urine cancer stem cells. Cancer Sci. 2017, 108, 2383-2392. [CrossRef]

95. Elbadawy, M.; Usui, T.; Yamawaki, H.; Sasaki, K. Emerging roles of C-Myc in cancer stem cell-related signaling and resistance to cancer chemotherapy: A potential therapeutic target against colorectal cancer. Int. J. Mol. Sci. 2019, 20, 2340. [CrossRef] [PubMed]

96. Abugomaa, A.; Elbadawy, M.; Yamawaki, H.; Usui, T.; Sasaki, K. Emerging roles of cancer stem cells in bladder cancer progression, tumorigenesis, and resistance to chemotherapy: A potential therapeutic target for bladder cancer. Cells 2020, 9, 235. [CrossRef] [PubMed] 
97. Usui, T.; Elbadawy, M.; Sasaki, K. Session 6: Advances in anticancer therapy. J. Vet. Pharmacol. Ther. 2018, 41, 28-30. [CrossRef]

98. Bartfeld, S.; Clevers, H. Stem cell-derived organoids and their application for medical research and patient treatment. J. Mol. Med. 2017, 95, 729-738. [CrossRef] [PubMed]

99. Takahashi, T. Organoids for drug discovery and personalized medicine. Annu. Rev. Pharmacol. Toxicol. 2019, 59, 447-462. [CrossRef]

100. Usui, T.; Sakurai, M.; Umata, K.; Elbadawy, M.; Ohama, T.; Yamawaki, H.; Hazama, S.; Takenouchi, H.; Nakajima, M.; Tsunedomi, R.; et al. Hedgehog signals mediate anti-cancer drug resistance in three-dimensional primary colorectal cancer organoid culture. Int. J. Mol. Sci. 2018, 19, 1098. [CrossRef]

101. Elbadawy, M.; Usui, T.; Yamawaki, H.; Sasaki, K. Development of an experimental model for analyzing drug resistance in colorectal cancer. Cancers 2018, 10, 164. [CrossRef]

102. Clevers, H. Modeling development and disease with organoids. Cell 2016, 165, 1586-1597. [CrossRef]

103. Abugomaa, A.; Elbadawy, M. Patient-Derived organoid analysis of drug resistance in precision medicine: Is there a value? Expert Rev. Precis. Med. Drug Dev. 2020, 5, 1-5. [CrossRef]

104. Gattazzo, F.; Urciuolo, A.; Bonaldo, P. Extracellular matrix: A dynamic microenvironment for stem cell niche. Biochim. Biophys. Acta 2014, 1840, 2506-2519. [CrossRef] [PubMed]

105. Shamir, E.R.; Ewald, A.J. Three-Dimensional organotypic culture: Experimental models of mammalian biology and disease. Nat. Rev. Mol. Cell Biol. 2014, 15, 647-664. [CrossRef] [PubMed]

106. Lengauer, C.; Kinzler, K.W.; Vogelstein, B. Genetic instabilities in human cancers. Nature 1998, 396, 643-649. [CrossRef]

107. Stratton, M.R.; Campbell, P.J.; Futreal, P.A. The cancer genome. Nature 2009, 458, 719-724. [CrossRef]

108. Alexandrov, L.B.; Nik-Zainal, S.; Wedge, D.C.; Aparicio, S.A.; Behjati, S.; Biankin, A.V.; Bignell, G.R.; Bolli, N.; Borg, A.; Borresen-Dale, A.L.; et al. Signatures of mutational processes in human cancer. Nature 2013, 500, 415-421. [CrossRef]

109. Sachs, N.; Clevers, H. Organoid cultures for the analysis of cancer phenotypes. Curr. Opin. Genet. Dev. 2014, 24, 68-73. [CrossRef]

110. Karthaus, W.R.; Iaquinta, P.J.; Drost, J.; Gracanin, A.; van Boxtel, R.; Wongvipat, J.; Dowling, C.M.; Gao, D.; Begthel, H.; Sachs, N.; et al. Identification of multipotent luminal progenitor cells in human prostate organoid cultures. Cell 2014, 159, 163-175. [CrossRef]

111. Ma, J.; Chang, K.; Peng, J.; Shi, Q.; Gan, H.; Gao, K.; Feng, K.; Xu, F.; Zhang, H.; Dai, B.; et al. SPOP promotes ATF2 ubiquitination and degradation to suppress prostate cancer progression. J. Exp. Clin. Cancer Res. CR 2018, 37, 145. [CrossRef]

112. Gao, D.; Vela, I.; Sboner, A.; Iaquinta, P.J.; Karthaus, W.R.; Gopalan, A.; Dowling, C.; Wanjala, J.N.; Undvall, E.A.; Arora, V.K.; et al. Organoid cultures derived from patients with advanced prostate cancer. Cell 2014, 159, 176-187. [CrossRef]

113. Beshiri, M.L.; Tice, C.M.; Tran, C.; Nguyen, H.M.; Sowalsky, A.G.; Agarwal, S.; Jansson, K.H.; Yang, Q.; McGowen, K.M.; Yin, J.; et al. A PDX/organoid biobank of advanced prostate cancers captures genomic and phenotypic heterogeneity for disease modeling and therapeutic screening. Clin. Cancer Res. Off. J. Am. Assoc. Cancer Res. 2018, 24, 4332-4345. [CrossRef] [PubMed]

114. Shoag, J.; Liu, D.; Blattner, M.; Sboner, A.; Park, K.; Deonarine, L.; Robinson, B.D.; Mosquera, J.M.; Chen, Y.; Rubin, M.A.; et al. SPOP mutation drives prostate neoplasia without stabilizing oncogenic transcription factor ERG. J. Clin. Invest. 2018, 128, 381-386. [CrossRef] [PubMed]

115. Blee, A.M.; He, Y.; Yang, Y.; Ye, Z.; Yan, Y.; Pan, Y.; Ma, T.; Dugdale, J.; Kuehn, E.; Kohli, M.; et al. TMPRSS2-ERG controls luminal epithelial lineage and antiandrogen sensitivity in PTEN and TP53-mutated prostate cancer. Clin. Cancer Res.Off. J. Am. Assoc. Cancer Res. 2018, 24, 4551-4565. [CrossRef] [PubMed]

116. Geng, C.; Kaochar, S.; Li, M.; Rajapakshe, K.; Fiskus, W.; Dong, J.; Foley, C.; Dong, B.; Zhang, L.; Kwon, O.J.; et al. SPOP regulates prostate epithelial cell proliferation and promotes ubiquitination and turnover of c-MYC oncoprotein. Oncogene 2017, 36, 4767-4777. [CrossRef] [PubMed]

117. Blattner, M.; Liu, D.; Robinson, B.D.; Huang, D.; Poliakov, A.; Gao, D.; Nataraj, S.; Deonarine, L.D.; Augello, M.A.; Sailer, V.; et al. SPOP mutation drives prostate tumorigenesis in vivo through coordinate regulation of PI3K/mTOR and AR signaling. Cancer Cell 2017, 31, 436-451. [CrossRef] [PubMed] 
118. Grasso, C.S.; Wu, Y.M.; Robinson, D.R.; Cao, X.; Dhanasekaran, S.M.; Khan, A.P.; Quist, M.J.; Jing, X.; Lonigro, R.J.; Brenner, J.C.; et al. The mutational landscape of lethal castration-resistant prostate cancer. Nature 2012, 487, 239-243. [CrossRef] [PubMed]

119. Lee, S.H.; Shen, M.M. Cell types of origin for prostate cancer. Curr. Opin. Cell Biol. 2015, 37, 35-41. [CrossRef] [PubMed]

120. Liu, W.; Lindberg, J.; Sui, G.; Luo, J.; Egevad, L.; Li, T.; Xie, C.; Wan, M.; Kim, S.T.; Wang, Z.; et al. Identification of novel CHD1-associated collaborative alterations of genomic structure and functional assessment of CHD1 in prostate cancer. Oncogene 2012, 31, 3939-3948. [CrossRef]

121. Shenoy, T.R.; Boysen, G.; Wang, M.Y.; Xu, Q.Z.; Guo, W.; Koh, F.M.; Wang, C.; Zhang, L.Z.; Wang, Y.; Gil, V.; et al. CHD1 loss sensitizes prostate cancer to DNA damaging therapy by promoting error-prone double-strand break repair. Ann. Oncol. 2017, 28, 1495-1507. [CrossRef]

122. Beltran, H.; Rickman, D.S.; Park, K.; Chae, S.S.; Sboner, A.; MacDonald, T.Y.; Wang, Y.; Sheikh, K.L.; Terry, S.; Tagawa, S.T.; et al. Molecular characterization of neuroendocrine prostate cancer and identification of new drug targets. Cancer Discov. 2011, 1, 487-495. [CrossRef]

123. Scher, H.I.; Heller, G.; Molina, A.; Attard, G.; Danila, D.C.; Jia, X.; Peng, W.; Sandhu, S.K.; Olmos, D.; Riisnaes, R.; et al. Circulating tumor cell biomarker panel as an individual-level surrogate for survival in metastatic castration-resistant prostate cancer. J. Clin. Oncol. Off. J. Am. Soc. Clin. Oncol. 2015, 33, 1348-1355. [CrossRef] [PubMed]

124. Dai, X.; Gan, W.; Li, X.; Wang, S.; Zhang, W.; Huang, L.; Liu, S.; Zhong, Q.; Guo, J.; Zhang, J.; et al. Prostate cancer-associated SPOP mutations confer resistance to BET inhibitors through stabilization of BRD4. Nat. Med. 2017, 23, 1063-1071. [CrossRef] [PubMed]

125. Janouskova, H.; El Tekle, G.; Bellini, E.; Udeshi, N.D.; Rinaldi, A.; Ulbricht, A.; Bernasocchi, T.; Civenni, G.; Losa, M.; Svinkina, T.; et al. Opposing effects of cancer-type-specific SPOP mutants on BET protein degradation and sensitivity to BET inhibitors. Nat. Med. 2017, 23, 1046-1054. [CrossRef] [PubMed]

126. Zhang, P.; Wang, D.; Zhao, Y.; Ren, S.; Gao, K.; Ye, Z.; Wang, S.; Pan, C.W.; Zhu, Y.; Yan, Y.; et al. Intrinsic BET inhibitor resistance in SPOP-mutated prostate cancer is mediated by BET protein stabilization and AKT-mTORC1 activation. Nat. Med. 2017, 23, 1055-1062. [CrossRef]

127. Yan, Y.; Ma, J.; Wang, D.; Lin, D.; Pang, X.; Wang, S.; Zhao, Y.; Shi, L.; Xue, H.; Pan, Y.; et al. The novel $\mathrm{BET}-\mathrm{CBP} / \mathrm{p} 300$ dual inhibitor NEO2734 is active in SPOP mutant and wild-type prostate cancer. EMBO Mol. Med. 2019, 11, e10659. [CrossRef]

128. Chua, C.W.; Shibata, M.; Lei, M.; Toivanen, R.; Barlow, L.J.; Bergren, S.K.; Badani, K.K.; McKiernan, J.M.; Benson, M.C.; Hibshoosh, H.; et al. Single luminal epithelial progenitors can generate prostate organoids in culture. Nat. Cell Biol. 2014, 16, 951-961. [CrossRef]

129. Floc'h, N.; Kinkade, C.W.; Kobayashi, T.; Aytes, A.; Lefebvre, C.; Mitrofanova, A.; Cardiff, R.D.; Califano, A.; Shen, M.M.; Abate-Shen, C. Dual targeting of the Akt/mTOR signaling pathway inhibits castration-resistant prostate cancer in a genetically engineered mouse model. Cancer Res. 2012, 72, 4483-4493. [CrossRef]

130. Carver, B.S.; Chapinski, C.; Wongvipat, J.; Hieronymus, H.; Chen, Y.; Chandarlapaty, S.; Arora, V.K.; Le, C.; Koutcher, J.; Scher, H.; et al. Reciprocal feedback regulation of PI3K and androgen receptor signaling in PTEN-deficient prostate cancer. Cancer Cell 2011, 19, 575-586. [CrossRef]

131. Pappas, K.J.; Choi, D.; Sawyers, C.L.; Karthaus, W.R. Prostate organoid cultures as tools to translate genotypes and mutational profiles to pharmacological responses. J. Vis. Exp. JoVE 2019. [CrossRef]

132. Robinson, D.; Van Allen, E.M.; Wu, Y.M.; Schultz, N.; Lonigro, R.J.; Mosquera, J.M.; Montgomery, B.; Taplin, M.E.; Pritchard, C.C.; Attard, G.; et al. Integrative clinical genomics of advanced prostate cancer. Cell 2015, 161, 1215-1228. [CrossRef]

133. Arora, V.K.; Schenkein, E.; Murali, R.; Subudhi, S.K.; Wongvipat, J.; Balbas, M.D.; Shah, N.; Cai, L.; Efstathiou, E.; Logothetis, C.; et al. Glucocorticoid receptor confers resistance to antiandrogens by bypassing androgen receptor blockade. Cell 2013, 155, 1309-1322. [CrossRef] [PubMed]

134. Mu, P.; Zhang, Z.; Benelli, M.; Karthaus, W.R.; Hoover, E.; Chen, C.C.; Wongvipat, J.; Ku, S.Y.; Gao, D.; Cao, Z.; et al. SOX2 promotes lineage plasticity and antiandrogen resistance in TP53- and RB1-deficient prostate cancer. Science 2017, 355, 84-88. [CrossRef] [PubMed]

135. Puca, L.; Bareja, R.; Prandi, D.; Shaw, R.; Benelli, M.; Karthaus, W.R.; Hess, J.; Sigouros, M.; Donoghue, A.; Kossai, M.; et al. Patient derived organoids to model rare prostate cancer phenotypes. Nat. Commun. 2018, 9 , 2404. [CrossRef] [PubMed] 
136. Xin, L. Cells of origin for cancer: An updated view from prostate cancer. Oncogene 2013, 32, 3655-3663. [CrossRef] [PubMed]

137. Visvader, J.E. Cells of origin in cancer. Nature 2011, 469, 314-322. [CrossRef] [PubMed]

138. Wang, Z.A.; Shen, M.M. Revisiting the concept of cancer stem cells in prostate cancer. Oncogene 2011, 30, 1261-1271. [CrossRef]

139. Vander Griend, D.J.; D’Antonio, J.; Gurel, B.; Antony, L.; Demarzo, A.M.; Isaacs, J.T. Cell-Autonomous intracellular androgen receptor signaling drives the growth of human prostate cancer initiating cells. Prostate 2010, 70, 90-99. [CrossRef]

140. Humphrey, P.A. Histological variants of prostatic carcinoma and their significance. Histopathology 2012, 60, 59-74. [CrossRef]

141. Goldstein, A.S.; Huang, J.; Guo, C.; Garraway, I.P.; Witte, O.N. Identification of a cell of origin for human prostate cancer. Science 2010, 329, 568-571. [CrossRef]

142. Stoyanova, T.; Cooper, A.R.; Drake, J.M.; Liu, X.; Armstrong, A.J.; Pienta, K.J.; Zhang, H.; Kohn, D.B.; Huang, J.; Witte, O.N.; et al. Prostate cancer originating in basal cells progresses to adenocarcinoma propagated by luminal-like cells. Proc. Natl. Acad. Sci. USA 2013, 110, 20111-20116. [CrossRef]

143. Drost, J.; Karthaus, W.R.; Gao, D.; Driehuis, E.; Sawyers, C.L.; Chen, Y.; Clevers, H. Organoid culture systems for prostate epithelial and cancer tissue. Nat. Protoc. 2016, 11, 347-358. [CrossRef]

144. Li, J.J.; Shen, M.M. Prostate stem cells and cancer stem cells. Cold Spring Harb. Perspect. Med. $2019,9$. [CrossRef] [PubMed]

145. Lawson, D.A.; Zong, Y.; Memarzadeh, S.; Xin, L.; Huang, J.; Witte, O.N. Basal epithelial stem cells are efficient targets for prostate cancer initiation. Proc. Natl. Acad. Sci. USA 2010, 107, 2610-2615. [CrossRef] [PubMed]

146. Wang, X.; Kruithof-de Julio, M.; Economides, K.D.; Walker, D.; Yu, H.; Halili, M.V.; Hu, Y.P.; Price, S.M.; Abate-Shen, C.; Shen, M.M. A luminal epithelial stem cell that is a cell of origin for prostate cancer. Nature 2009, 461, 495-500. [CrossRef] [PubMed]

147. Liu, X.; Grogan, T.R.; Hieronymus, H.; Hashimoto, T.; Mottahedeh, J.; Cheng, D.; Zhang, L.; Huang, K.; Stoyanova, T.; Park, J.W.; et al. Low CD38 identifies progenitor-like inflammation-associated luminal cells that can initiate human prostate cancer and predict poor outcome. Cell Rep. 2016, 17, 2596-2606. [CrossRef] [PubMed]

148. Park, J.W.; Lee, J.K.; Phillips, J.W.; Huang, P.; Cheng, D.; Huang, J.; Witte, O.N. Prostate epithelial cell of origin determines cancer differentiation state in an organoid transformation assay. Proc. Natl. Acad. Sci. USA 2016, 113, 4482-4487. [CrossRef] [PubMed]

149. Leong, K.G.; Wang, B.E.; Johnson, L.; Gao, W.Q. Generation of a prostate from a single adult stem cell. Nature 2008, 456, 804-808. [CrossRef]

150. Jiao, J.; Hindoyan, A.; Wang, S.; Tran, L.M.; Goldstein, A.S.; Lawson, D.; Chen, D.; Li, Y.; Guo, C.; Zhang, B.; et al. Identification of CD166 as a surface marker for enriching prostate stem/progenitor and cancer initiating cells. PLoS ONE 2012, 7, e42564. [CrossRef]

151. Wang, Z.A.; Mitrofanova, A.; Bergren, S.K.; Abate-Shen, C.; Cardiff, R.D.; Califano, A.; Shen, M.M. Lineage analysis of basal epithelial cells reveals their unexpected plasticity and supports a cell-of-origin model for prostate cancer heterogeneity. Nat. Cell Biol. 2013, 15, 274-283. [CrossRef]

152. Shibata, M.; Shen, M.M. Stem cells in genetically-engineered mouse models of prostate cancer. Endocr. Relat. Cancer 2015, 22, T199-T208. [CrossRef]

153. Kwon, O.J.; Zhang, L.; Xin, L. Stem cell antigen-1 identifies a distinct androgen-independent murine prostatic luminal cell lineage with bipotent potential. Stem Cells 2016, 34, 191-202. [CrossRef] [PubMed]

154. Agarwal, S.; Hynes, P.G.; Tillman, H.S.; Lake, R.; Abou-Kheir, W.G.; Fang, L.; Casey, O.M.; Ameri, A.H.; Martin, P.L.; Yin, J.J.; et al. Identification of different classes of luminal progenitor cells within prostate tumors. Cell Rep. 2015, 13, 2147-2158. [CrossRef]

155. Leroy, B.E.; Northrup, N. Prostate cancer in dogs: Comparative and clinical aspects. Vet. J. 2009, 180, $149-162$. [CrossRef] [PubMed]

156. Palmieri, C.; Lean, F.Z.; Akter, S.H.; Romussi, S.; Grieco, V. A retrospective analysis of 111 canine prostatic samples: Histopathological findings and classification. Res. Vet. Sci. 2014, 97, 568-573. [CrossRef] [PubMed]

(C) 2020 by the authors. Licensee MDPI, Basel, Switzerland. This article is an open access article distributed under the terms and conditions of the Creative Commons Attribution (CC BY) license (http://creativecommons.org/licenses/by/4.0/). 